\title{
Academy under fire on 'wetlands' definition
}

Washington. In a cautionary twist to the debate about putting federal regulations on a more 'scientific' footing, a US National Academy of Sciences study on wetlands has come under fire from congressional sponsors of a bill whose scientific foundation the study calls into question.

Bud Shuster (Republican, Pennsylvania) and other authors of the Clean Water bill, which the House of Representatives was expected to pass this week, have accused the academy of "playing politics" by releasing its wetlands report a day before debate on the bill.

The academy report does not mention specific legislation. But it does call for a much broader definition of wetlands than is included in the current version of the bill.

At stake is the fate of the nation's swamps, bogs and other wetlands, which are protected by the federal government. Seventy-five per cent of wetlands in the lower 48 states are privately owned, and Shuster and his allies want to narrow the definition of a wetland, removing federal protection from an estimated 50 per cent of existing wetlands so they can be developed for other purposes.

The legal definition of a wetland has been controversial for nearly a decade. Federal agencies responsible for delineating wetlands still follow guidelines prepared in 1987 by the Army Corps of Engineers. Two attempts to rewrite the delineation manual, in 1989 and again in 1991, failed because of the political heat they caused.

The Shuster bill borrows language from the 1991 draft, which environmentalists criticized for excluding too many wetlands. One of its criteria for defining a wetland is that water should be present at the surface for 21 consecutive days during the growing season. Three factors would also each have to be present: wetlands hydrology, characteristic soils and characteristic vegetation.

But the academy study says that the 21day threshold is not a useful criterion, and would exclude many bona fide wetlands. It also says that in many cases soil and vegetation are enough to identify a wetland without resorting to hydrology.

Even more controversially, the report clearly states that regions with permafrost in Alaska and agricultural wetlands - both of which are political hot potatoes - are in fact wetlands. Furthermore, even though it finds that the government's manual on delineating wetland needs to be improved, it contends that current federal wetlands policies are generally based on sound science.

That conclusion has upset property-rights advocates in Congress, who base much of their argument on claims that the government has over-regulated wetlands. During the House debate, Shuster and other spon- sors of the bill went on the attack.

"The American people should know that that study was funded by the [Environmental Protection Agency (EPA)] bureaucrats downtown," said Shuster. (Congress ordered the wetlands study in 1992 and authorized EPA to pay for it, as is common practice for federal agencies that require the academy's outside advice.) "So, sadly, the

\section{IMAGE UNAVAILABLE FOR COPYRIGHT REASONS}

- not the legislative calendar - that determined its release date.

But politics did play a role. Boehlert, Gilchrest and other opponents of the Shuster bill had attempted to get House Republican leaders to delay debate on the bill until the academy study was released.

When they were refused, and it appeared the report would not come out in time, they \& urged the academy to speed up its procedures, and the release was moved forward from 18 May to 9 May. But, laments a Boehlert staff member who would have liked it even sooner, "there's no way to pressure the academy," given its thorough peer review.

With only a day to draw on the study for ammunition, Boehlert, Gilchrest and their allies introduced amendments substituting language on wetlands definition more in line with the academy report. But these were defeated easily, and by the end of last week the bill appeared to be on the verge of approval.

The debate now moves to the Senate, which may be more inclined to incorporate the academy's conclusions into its own bill, or even shelve consideration of the Clean Water bill temporarily rather than wade into the wetlands versus land owners debate. Administration officials have threatened a veto if the House version of the bill makes it to the president's desk.

Despite the furore in Congress, Lewis says the panel members themselves argued very little over the scientific issues, and that the report represents a "very deep consensus" among wetlands experts.

The irony is that Congress specifically asked the academy three years ago to help settle a question that had become politically intractable. But that was before conservative Republicans took charge of the House. Now, says a member of Gilchrest's staff, "they're not going to let anything as silly as science get in the way." Tony Reichhardt was the academy's internal review process

\section{Italian minister seeks more money for space}

Munich. Giorgio Salvini, Italy's research minister, has promised to ask the government to increase the annual budget of the Italian Space Agency (ASI) from IL850 billion (US\$503 million) to more than IL1200 billion by transferring money from other government departments, in particular the ministry of industry.

Salvini told a meeting of the parliamentary committee for innovation and technology that he wants ASI to honour its international commitments, but also to have the same balance between national and international space projects as France and Germany. The space agencies of both these countries dedicate around half of their budgets to national programmes.

Already IL700 billion of this year's Italian space budget has been allocated to international projects, mostly the European Space Agency (ESA) and others mounted bilaterally with the United States. As a result, little is left for national projects. ASI's director general, Mario Calamia, has been trying to renegotiate some international contracts.

But at the committee meeting Salvini reassured Jean-Marie Luton, director general of ESA, that despite its financial difficulties, Italy would "strive to maintain commitments it has already made to future ESA programmes".

Alison Abbott 